\title{
METHODS OF PROOF AND EVIDENTIARY REQUIREMENTS IN DIVORCE CASES: AN ISLAMIC PERSPECTIVE*
}

\author{
Zulfakar Ramlee and \\ Normi Abdul Malek**
}

\begin{abstract}
The bulk of Shariah Court cases nowadays involve matters pertaining to the dissolution of marriage. The most common ones are talāq, ta' līq and fasakh. The reason as to why the Shariah Courts are crammed with these cases is not merely due to the increasing number of divorce cases but can also be attributed to the difficulty in proving them. Today, as lifestyles become more complicated, țalāq is no longer the same as țalāq, previously understood. The husband no longer pronounces it openly or orally. Current technology such as SMS and email has overshadowed the sanctity of talāq. The situation becomes worse when the sender, that is the husband, denies it.

To obtain dissolution of marriage via ta 'līq or fasakh, in most cases, has proved to be a
\end{abstract}

This article is a revised version of a paper presented at the International Family Law Conference organized by Ahmad Ibrahim Kulliyyah of Laws at Crown Princess Hotel, Kuala Lumpur, 16-17 January 2007.

Assistant Professors, Ahmad Ibrahim Kulliyyah of Laws, International Islamic University Malaysia. 
nightmare. There are many causes that contribute to it; ranging from the complexity of the subject itself, the provisions of the law and how to apply them, misconception on the methods of proof, and the wrong imposition of burden of proof. Due to all these factors, it is simply concluded by one section of the society as 'gender discrimination' and sometimes the blame has been put on the Shariah Court itself.

This paper intends to provide some suggestions and solutions to the problems mentioned above. It is hoped that the courts and those involved in legal suits would be ready to accept the wider concept of evidence without confining themselves merely to the requirements of two male witnesses.

\section{INTRODUCTION}

Most of Shariah Court cases involve matters pertaining to the dissolution of marriage. There are many types of dissolution of marriage in Islamic Law including talāq, ta 'lìq, khulu', fasākh and li'än. The question arises as to how to prove the existence of such divorce in the court. Thus, one of the important and pertinent issues that needs to be examined pertaining to these divorce matters is the method of proving them.

Today, as lifestyles are more complicated, talāq is no longer the same as talāq that was previously understood. In many cases talāq is pronounced indirectly rather than directly, and in extreme cases it is no longer pronounced verbally. The problem becomes more complicated when the husband denies pronouncing taläq and the wife is unable to support her allegation of talāq with 'strict proof' as required by traditional jurists. The fact that some judges as well as jurists fail to appreciate the 'traditional and classical views of respected jurists' has worsened the situation. Some judges of the Shariah Courts still adhere to this strict requirement because much emphasis is given to the classical texts without rationalising and understanding the underlying principles behind them.

Current technologies such as SMS and e-mail overshadow the sanctity of talāq. The situation gets worse when the sender i.e. the husband denies it. What is the position if the message is proved to have 
originated from the husband but he keeps denying it? Is there any remedy given to the wife in such a case?

This paper examines the above issues and proposes some solutions and suggestions.

\section{WHY DOES A CLAIM NEED TO BE PROVED?}

The answer is very simple: Any litigation involves two parties namely the claimant/prosecutor and the defendant/accused person. To win the claim, it needs to be supported by proof. Failure to support the claim with proof or evidence will generally cause the claim to be rejected. This concept is known as burden of proof ( ' $i b$ ' al-Ithbat) whereby the burden is said to be on the claimant because normally what he/she claims is contrary to the original presumption or apparent fact. ${ }^{1}$ Therefore, he/ she must bring support in the nature of evidence to prove his allegation. ${ }^{2}$ The concept of burden of proof under Islamic law is well established. ${ }^{3}$ Suffice to quote a few examples from the sayings of the Prophet:

"If people's claims were accepted at face value, some persons will claim other people's blood and properties, but oath is on the person who denies." 4

In another hadīth:

1 The maxim states 'al-Aṣl barā'ah al-dhimmah.' Al-Sayūṭī, Jalāl alDīn, Al-Ashbāh wa al-Nazā'ir, 1st edn., (Beirut: Dār al-Kutub al'Ilmiyah,1983), 53. See also Tyser, CR, The Mejelle, English translation from Majallah al-Ahkām al- 'Adliyyah, (Lahore: Law Publishing Co, 1967), art. 8.

$2 \quad$ Article 77 of the Mejelle states: "The purpose of evidence is to prove what is contrary to the apparent fact. The purpose of the oath is to ensure the continuation of the original state.” See ibid.

3 See the Quranic verses on the subject such as in Al-Baqarah: 111; AlAnbiyā': 24. Please read the presiding verses to understand proper context of this verse; Al-Naml: 64. See also verses 27-28.

$4 \quad$ Sahīh Muslim, English trans. by A.H. Siddiqi, (Lahore: Sh. Muhammad Ashraf, 1976), vol. 3, 927. See also Al-Baihaqī, Sunan al-Kubra, (India: Maktabah Majlis Dā'irah al-Ma ārif al-Usmāniyah, 1354H), vol. 10, 252. 
'Evidence is on the claimant and oath is on the defendant." ${ }^{5}$

It is clear that in any claim, the claimant must, according to the above general rule, produce evidence to support his allegation. ${ }^{6}$ It also implies that no one can claim someone's right unless with proof, and no one could be held responsible unless with evidence. ${ }^{7}$

Another example to show the application of this concept is the case of Ash'ath Ibn Qais. 'Ash'ath ibn Qais is reported to have said, 'There was a (piece of) land between me and a Jew. He disputed with me.' I brought him to the Holy Prophet, upon which Allah's Messenger said to me: 'Have you any evidence (in your support)? I replied: 'No.' The Holy Prophet said to the Jew: 'Do swear.' ${ }^{\text {' }}$

The requirements for discharging the burden of proof has been embodied in the Qānūn al-Shahādah Pakistan $1984^{9}$ as well as in the Shariah Court Evidence Act (Federal Territories of Malaysia) 1997 ('SCEA'). ${ }^{10}$ Section 73 SCEA 1997 provides:

“(1) Whoever desires any court to give judgment as to any legal right or liability which is dependent on the existence of facts which he asserts must prove that those facts exist.

(2) When a person is bound to prove the existence of any fact, it is said that the burden of proof lies on that person.”

5 Al-Bayyinah 'ala al-Țālib wa al-Yamin 'ala al-Mațūb, Al-Baihaqī, Sunan al-Kubrā, vol.10, 252. Al-Ramlī, Sham al-Dīn Muḥammad, Nihāyah al-Muhtāj 'ilā Sharh al-Minhājj, (Cairo: Mațba'ah Mușțafa al-Bābī, 1962), vol. 8, 333; See also Ibn Qudāmah, Al-Mughnī, (Beirut: Dār al-Kutub al-'Ilmiyyah, n.d.), vol. 10, 4.

$7 \quad$ See Article 77 of the Mejelle "Evidence is for the proof of what is not clear, an oath is for the confirmation of what is presumed." Abū 'Abdullah Muhammad, Sunan Ibn Mājah, English trans. by Muḥammad Tufail, (Lahore: Kazi Publications, 1985), vol. 3, 386.

$9 \quad$ See Sections 117 and 118.

$10 \quad$ Hereinafter referred to as SCEA 1997. 
The Malaysian Shariah Courts in some cases have correctly addressed the issue but in some other cases seem to be unclear on the principles. In the case of Daing Kelthom \& Others v. Mohd. Aruwa, ${ }^{11}$ the Plaintiffs claimed the right of inheritance against the defendant. The court applied correctly the above provision. In the case of Aishah bte Abdul Rauf $v$ Wan Mohd. Yusof, ${ }^{12}$ the Shariah High Court, in allowing the husband's application to practice polygamy, seemed to impose the burden of proof on the wife. In this case, the wife was required to prove that her husband did not fulfill the required conditions. Nevertheless, on appeal, the Shariah Appeal Court altered the decision and held that the burden of proof was on the husband to prove to the court that he had satisfied the four conditions required before he could be allowed to enter into polygamous marriage. ${ }^{13}$

Section 74 states:

"The burden of proof in a suit or proceeding lies on that person who would fail if no evidence at all were given on either side."

This section covers the situation where both sides are in the original position and no one is actually in the state of contradicting the apparent fact. ${ }^{14}$ The case of Azizan bin Marzuki v. Maharum binti Abdullah $^{15}$ is a good example to illustrate this section. The appellant

(2003) 16 JH 127. See also Norazaha v. Rohana (1999) 13 JH 91. (1990) 7 JH 152. See also Ramona Juita v. Engku Nazarudin, (1999) 18 $\mathrm{JH} 215$.

See also Rajamah v. Abdul. Wahab (1990) 7 JH 171. In this case the Shariah Subordinate Court in allowing the husband's application to practise polygamy seemed to impose burden of proof on the wife to prove that her husband did not fulfill the conditions to enter into polygamous marriage. On appeal, The Appeal Committee held that burden of proof was on the husband to prove to the court that he had satisfied all the conditions required under section 23 of Selangor Islamic Family Law Enactment 1984.

See the case of Norlia Abd. Aziz v. Md. Yusof A.Rahman (2004) $18 \mathrm{JH}$ 133 where the court referred to this section but it seems to be wrongly applied to prove Harta Sepencarian. (2002) 15 JH 13. 
had been ordered to pay RM1,000.00 per month as maintenance for his four children with the first wife (Respondent). Later on, the Appellant at the lower court applied for an order to reduce this amount of payment to RM600.00 per month. He argued that due to the change of his status quo, he was unable to comply with such order. The appellant managed to prove his contention while the respondent was unable to convince the court that the appellant could still afford to pay the original amount. In this case, although no reference was made to section 74 , the principle seems to be applied correctly. The Shariah Court of Appeal held:

“Although the court seems to agree with the respondent's submission that to prove maintenance by receipt is very difficult, the court is of the view that the burden is still on the respondent who should bring strong evidence to support her contention that the appellant despite having changed the status quo, is still capable to pay RM1,000.00 per month as previously ordered by the court." 16

With regard to types of proof in Islam, it is submitted that the wider concept of proof (bayyinah) as agreed by the majority of the jurists need to be adhered to. ${ }^{17}$ Interestingly, section 3 of the SCEA 1997 has covered the very wide concept of proof i.e. evidence. It provides:

"Bayyinah means evidence which proves a right or
interest and includes qarinah"

In defining the meaning of 'evidence,' the SCEA 1997 includes all oral evidence given in the court that has been made by any person

$16 \quad$ Ibid., at 20. It is also interesting to note here that when the court used the phrase 'very strong' or in Malay 'yang cukup kuat' this means the court required the standard of 'beyond reasonable doubt' (zan alghälib) which in the view of the writers is very high. See further under sub-topic 'How to Prove Fasakh' for a detailed discussion on this point.

17 Ibn Qayyim, Sham al-Dīn Muhammad al-Jauziyah, al-Turuq alHukmiyyah fi al-Siyāsah al-Shar'iyah, ed. Zakariya 'Amirat, (Beirut: Dār al-Kutub al-'Ilmiyyah, 1995), 19; Ibn Farhūn, Tabṣirat al-Hukkām fì Usūl al-Aqụiyah wa Manāhij al-Aḥkām, ed. Jamāl 'Ashli, 1st edn., (Beirut: Dār al-Kutub al-'Ilmiyyah, 1995), vol. 2, 101. 
including a non-Muslim ${ }^{18}$ or even a minor; ${ }^{19}$ documentary evidence either public or private and also expert opinion. ${ }^{20}$ The recent Shariah Court case of Re Nyonya binti Tahir ${ }^{21}$ has shown an improvement on this concept. Here, the court admitted evidence from non-Muslim witnesses and also documentary evidence.

\section{METHODS OF PROVING TALĀQ}

Literally, talāq means to release from bondage. ${ }^{22}$ Technically, talāq means terminating the bond created by the marriage contract with explicit or implicit words. Talāq is the most common form of divorce in Islamic Law. In Malaysia, provisions with regard to talāq can be seen under various Islamic Family Law States Enactments. ${ }^{23}$

All jurists are in agreement that talāq will be valid and enforceable whenever the husband affirms it (Iqrär) or such pronouncement is made in front of at least two male witnesses (shahädah). ${ }^{24}$ This is actually

18 See section 83(2) “A non-Muslim shall be competent to give bayyinah ...”

19 See section 83(4) "A person is not baligh ... is competent to give bayyinah ..."

$20 \quad$ See section 33. (2006) JH 221.

Al-Jarjānī, Ta rî̉fät, (Beirut: Dār al-Kutub al- 'Ilmiyyah, 1995), 141.

See for example s. 47 of the Islamic Family Law (Federal Territories) Act 1984.

24 The majority of jurists are of the view that witnesses are not required to witness the pronouncement of taläq. The Qur'anic verse on the subject i.e. verse 2 of surah al-Ṭalāq is a mere recommendation. See Wahbah al-Zuhaili, Fiqh \& Perundangan Islam, Malay trans. by Syed Ahmad Syed Hussain et al, (Kuala Lumpur: Dewan Bahasa dan Pustaka, 2001), vol. 7, 596. See also Saukani, Nail al-Autār, Malay trans. by Mu'ammal Hamidy et al, (Kuala Lumpur: Victory Agencie, 1994), vol. 5, 2358. In fact, this argument is clearer if we discuss it under the concept of al-Istishhäd (act of witnessing the event). The real issue on the number of witnesses and the need of witnesses arise when we discuss it under the concept of al-Ishhäd (act of testifying in the form of alshahadah in the court). 
based on the principle of the best evidence rule as both methods attain the level of certainty (yaqin).

Other than these two methods, the jurists have different views. For example, in the situation where the wife is only able to bring one male witness to support her claim, the jurist like Ibn Hazm accepted this kind of proof provided the wife must take an oath. ${ }^{25}$ Despite disagreement from some jurists on this method, Ibn Hazm even allows the wife's claim if she is able to support it with the testimony of two women together with her oath. ${ }^{26}$

A question arises as to the position if there is no such admission from the husband and no single witness except the wife. Will the husband, in this kind of case, be allowed to swear in order to refute the wife's claim? Can the wife take an oath to support her claim?

According to the classical jurists, there are two views with regard to the application of oath (yamin) in talāq cases. The first view does not allow oath to be administered in matrimonial matters including talāq. This is the view of the Hanafĩs. ${ }^{27}$ They are of the opinion that oath can only be administered in cases of property. As taläq cannot be considered as property (as it cannot be replaced or substituted badāl), oath is not allowed in this case.

The second view allows the application of oath in matrimonial cases on the basis of the saying of the Prophet that "If people's claim be accepted at face value ....”28 It is also based on the hadith of Rukanah who had taken oath in confirming the type of taläq that he had pronounced. This is mainly the Shāfi 'îs' opinion which construes the word properties (amwāl) to cover all matrimonial matters including talāq. ${ }^{29}$

25 Ibn Hazm, Abī Muḥammad 'Alī bin Aḥmad, Al-Muhallāa, (Beirut: Dār Ihyā' al-Turāth al-'Arabī, 1997), vol.10, 274.

26 Mohammad al-Zuhailī a contemporary jurist agrees on this view. See Mohammad al-Zuhailī, Wasā'il al-Ithbāt, (Damsyik: Maktabah Dār alLubnān, 1994) vol. 1, 206.

27 Wahbah Al-Zuhaily, Fiqh \& Perundangan Islam, vol. 6, 609. However, according to al-Khașāf oath can be administered in talāq cases. See Sharḥ Adab al-Qādi, (Beirut: Dār al-Kutub al-'Ilmiyyah, 1994), 157.

$28 \quad$ Sahìh Muslim, vol. 3, 927.

29 Al-Shīrāzī, Abī Ishāa Ibrāhīm, al-Muhadhdhab, (Beirut: Dār Ihyā’ alTurāth al-'Arabī, 1994), vol. 2, 130; Ibn Abī Dam, Shihābuddīn, Kitāb Adab al-Qad̄ā', (Beirut: Dār al-Kutub al-'Ilmiyyah, 1987), 189. 
The main issue here is what is the position when the wife claims that the husband did pronounce taläq despite his denial and there is no direct evidence to support the allegation? Based on the first view, the husband will not be asked to swear to deny that he did divorce his wife. The wife's failure to prove her allegation will strengthen the husband's denial. Consequently, the original status of the parties is maintained i.e. both are still husband and wife. The law presumes the absence of talāq.

However, if we rely on the second view that allows oath to be administered, the matter will be divided into three categories. Firstly, the husband will be asked to swear that he never pronounced taläq towards his wife. Upon doing so, the wife's claim will be rejected and both parties will be presumed to be in their original position i.e. they are still husband and wife. The reason is simple. The wife's claim is contrary to an apparent fact, thus she needs to prove it. Her failure to prove will justify the husband taking an oath to maintain the status quo. ${ }^{30}$

Secondly, the husband will be asked to swear but he refuses to do so. His refusal indicates the possibility of the truth of the claim made against him. This is a form of qarinah. ${ }^{31}$ Nevertheless, this qarinah is not strong enough to pass judgment against the husband. Therefore, this school of thought puts another condition that is known as 'yamin mardüdah's2 whereby the wife will be asked to swear. If she swears, her claim will be accepted.

Thirdly, if there is/are qarinah ${ }^{33}$ to support the wife's claim such as at the time talāq was allegedly uttered, both of them were in the state of quarrelling or fighting. Another example of qarinah is when the wife

However, some Shāfi 'īs jurists do classify talāq under special case. See also Sharbīnī, Muḥammad al-Khațīb, Mughnī al-Muhtājo, (Beirut: Dār al-Kutub al-' Ilmiyyah, 2000), vol. 6, 416. Article 77, the Mejelle.

In this context, qarinah means assumption or even adverse inference. For further detail see Zulfakar Ramlee, "Al-Qarinah: Pemakaiannya dalam Litigasi Mal dan Jenayah” in Nasimah Hussin et al., UndangUndang Islam Jenayah, Keterangan dan Prosedur, Siri Perkembangan Undang-Undang di Malaysia, (Kuala Lumpur: Dewan Bahasa \& Pustaka, 2007), vol. 13, 187.

An oath which is to be taken by the plaintiff due to the defendant's refusal to swear.

Qarinah here refers to circumstantial evidence as one kind of proof. 
has been warned several times by the husband that he will divorce her or when there are witnesses who have heard directly from the husband that he intended to divorce his wife.

The question is that, in the presence of strong qarinah such as the above, ${ }^{34}$ should the court ask the husband to swear denying the fact (yamin al-nafi) or should the court proceed to ask the wife to swear? In the case where the court straight away asks the husband to swear, it seems that the court does not consider the above qarinah as a form of bayyinah. In this situation, is it acceptable if the husband simply takes an oath in order to deny the wife's claim? In this circumstance, the court should allow the wife to swear in the presence of strong qarinah. Here, strong qarinah means evidence that has attained the degree of beyond reasonable doubt (zan al-ghälib). ${ }^{35}$

One might argue why are we very much concerned with regard to proving of $\operatorname{tala} q$ by the wife if the husband denies it. The answer is that the denial might not be so significant if the case fell under talāq $\operatorname{raj}^{\prime} i$ as the husband can revoke the divorce. But in the case where the wife has already been divorced twice or in triple talāq cases, the issue will be very crucial. This is because according to Islamic Law, if the wife has been divorced for the third time, there is no longer any opportunity for the husband to revoke the divorce. The rule is that, the wife must marry another person and the marriage must be consummated and then only the husband may remarry his former wife. ${ }^{36}$ The question arises as to what happens if the husband denies that he pronounced the third divorce but the wife says she heard it clearly. The only defect here is the wife fails to bring two witnesses. In this case, should we allow the husband to go on with the marriage despite the fact that he has indeed pronounced three irrevocable divorces due to the fact that the wife fails to provide two witnesses? Or should we allow the wife to bring other

34 If all the above-mentioned qarinah (pl. qarä 'in) are combined together, it would form a strong qarinah.

35 Hanafĩ school does accept women's testimony in the case of marriage and divorce due to the fact that these cases need not be proved at the level of certainty (yaqin) but suffice at the degree of beyond reasonable doubt (zan al-Ghālib), see Al-Marghinānī, 'Alī ibn Abī Bakr, The Hedaya, English translation by C. Hamilton, (Karachi: Darul Ishaat, 1989), vol. 2, 668. See Al-Qur'ān (2:230). 
kinds of evidences in order to avoid the parties from continuing living in $\sin$ ?

If there is an opinion ${ }^{37}$ that the wife in this type of case would not be considered guilty if she killed her husband in order to prevent herself from continuing committing sin; thus, to entertain the wife's claim by allowing other kinds of evidences to be used is certainly much more preferred. The wife's claim should therefore be upheld even though her allegation is only based on bayyinah or strong qarinah provided it is corroborated with the wife's oath. ${ }^{38}$

\section{TALĀQ VIA SMS OR E-MAIL}

With regard to talāq via SMS or e-mail, two legal issues are involved. The first issue is the legality of talāq based on electronic devices. Again, this invites fresh ijtihād as it was never discussed by the previous jurists. Fortunately, the basis of it has been nicely formulated. As this kind of talāq is in written form and not in verbal form, it falls under the scope of 'talāq by writing' as thoroughly discussed by the previous jurists. According to the Hanafis, ${ }^{39}$ taläq in writing can be divided into two categories. Firstly, a writing which bears the name of the writer (i.e the husband) and it is properly addressed and directed to the wife. For this type of writing, if the words used are explicit (sarịh), talāq is effective even though the husband has no intention to divorce his wife. Secondly, a writing which does not bear the name of the writer (i.e. the husband) and is not properly addressed or directed to the wife. For this category of writing, taläq is not effective even though the words

37 Hașkafī, Muhammad 'Alauddin, Durr al-Mukhtār Sharh Tanwīr alAbșār, English trans. by B.M. Dayal, (New Delhi: Kitab Bhavan, 1992), 230.

38 As in the case of al-qasāmah (compurgation i.e. repeated oaths taken either by a suspected person or the legal heirs in homicide cases in which the killer could not be certainly identified), the claimant's claim will be accepted if supported by qarinah or lauth together with his fifty oaths. See also al-Shīrazī’, Abī Ishāq Ibrāhīm, al-Muhadhdhab, (Beirut: Dār Ihyā' al-Turāth al-'Arabī,1994), vol. 2, 407.

39 Haṣkafī, Muhammad 'Alauddin, Durr al-Mukhtār Sharh Tanwīr alAbșār, 127. 
used are explicit unless there is an intention to divorce the wife on the part of the husband.

The majority of jurists including the Shāfi ${ }^{c} 1 \mathrm{is}^{40}{ }^{4}$ Mālikis $^{41}$ and the Hanbalīs (the stronger view) are of the opinion that taläq in writing will only be effective if it is coupled with intention. Thus, in the case of talāq via SMS, following the views of the majority jurists, it will only be effective if it is coupled with intention on the part of the husband to divorce his wife. This is the situation in Malaysia based on the fatwa issued by the Committee of the National Fatwa Council. ${ }^{42}$

The second issue arises when the husband denies that he sent such a message, or in other words, he challenges the authenticity or originality of the message. Here, the wife who contends that her husband has sent the message must bear the burden to prove it. Of course, as discussed earlier, if the wife is able to bring two male witnesses who saw the husband typing the divorce message, it will be regarded as good as an iqrār (admission). But what happens if she is unable to support it? The only proof she has is that the divorce message was sent from her husband's mobile phone. In this situation, the husband will be asked to swear. If he does swear, then the claim of the wife would be dismissed and both of them will still be considered as husband and wife. ${ }^{43}$

If the husband refuses to swear or there are strong qarinah that indicate the possibility of the husband's action, another issue that needs to be determined is whether the court should ask the wife to swear instead of the husband. In solving this complicated issue as well as taking into consideration 'fasād al-zaman'(period of corruption) whereby people no longer care about the implications of oath and punishment in the Hereafter, it is submitted that qarinah sometimes plays a very important role. Hence, in the absence of direct evidence, the court should use indirect evidence (i.e. qarinah) together with judicial discretion. However, these should be exercised prudently and cautiously. Finally,

\footnotetext{
$40 \quad$ Al-Shīrāzī, Al-Muhadhdhab, vol. 2, 106.

41 Ibn Juzai, Al-Qawānīn al-Fiqhiyyah, (Beirut: Dār al-Kutub al'Ilmiyyah), 230.

42 See http:/www.islam.gov.my/e-rujukan/sms.pdf

$43 \quad$ See Nor Aniza bte Idris v Mohammad Fauzi bin Ahmad [2006] 3 ShLR 102. See also Nasran Mohamad and Naim Mokhtar, "Divorce Through SMS from the Perspective of Fiqh and Islamic Family Law,” [2004] 1 ShLR 1 .
} 
there is a crucial need to caution and advise the party who will take an oath about the serious implications of taking a false oath.

\section{HOW TO PROVE FASAKH}

Literally, fasakh, which comes from the root word means to annul or to rescind. Technically, it means the annulment of the marital contract by the court after one of the parties to the marriage applies for it or in some circumstances when the court feels that the marriage needs to be annulled. All the states in Malaysia provide the grounds for fasakh in their respective enactments. ${ }^{44}$ Among the reasons that can be used in order to apply for fasakh are desertion, failure to provide maintenance, imprisonment, failure to perform conjugal duties, impotence, insanity and cruelty.

For the purpose of proving, fasakh can be divided into two. Firstly, if there is the allegation of a civil wrong such as failure to provide maintenance, desertion and failure to perform conjugal duties. Secondly, if there is an allegation of criminal conduct such as cruelty and apostacy.

To prove one of these grounds, one must adhere to this division. Each division requires a different standard of proof. For example, if the ground for fasakh is the husband's failure to provide maintenance, then the standard of proof which is required to prove this fact, is on the balance of probabilities (zan) ie. a civil standard. ${ }^{45}$

In the case of Fatimah binti Osman v. Norazmi bin Tukiban ${ }^{46}$ the wife made an application for fasakh on two reasons. The first reason, was that the defendant had failed to carry out his duties as husband and father of three children by not providing maintenance. The second reason was that the defendant had made the plaintiff's life miserable by his habit in using a certain item in order to get sexual pleasure during intercourse that had caused persistent pain on the sexual organ of the

$44 \quad$ For example, see s. 52 of Islamic Family Law (Federal Territories) Act 1984 for Federal Territories.

45 See Halsbury's Laws of Malaysia, (Kuala Lumpur: Malaysian Law Journal, 2002), vol. 14, 594. See also Muḥammad al-Zuhaili, Wasā'il al-Ithbät, vol. 2, 741. See the case of Mustafa v. Smt. Khursida, AIR 2006 Rajasthan 31.

$46 \quad$ (2001) 14 JH 65. 
wife. The court had focused on the second reason because it considered this as the main factor of the application. However, the application was rejected by the court on the ground that there was no concrete evidence adduced by the wife. Despite the medical reports that had been presented by the wife, the court insisted on the evidence of two male witnesses because this case falls under fasakh. ${ }^{47}$ This case clearly shows that the court had applied the highest standard of proof i.e. yaqin in proving a claim of fasakh despite the ground of fasakh related to sexual conduct only.

For the second category, where being the application for fasakh is based on the ground of cruelty of the husband, this amounts to a criminal allegation against the husband. In this case, the wife or petitioner needs to prove this fact on the criminal standard i.e. beyond reasonable doubt (zan al-ghālib). This standard may be satisfied by calling one male witness that fulfils the requirement of al-shahädah. Alternatively, it may be achieved by any form of bayyinah including qarinah. ${ }^{48}$ What is most important is that the case must be proved not lesser than the standard of beyond reasonable doubt.

Interestingly, the Federal Territories Shariah Appeal Court in the case of Abdul Hanif v. Rabiah ${ }^{49}$ had accepted qarinah of quarrelling between the parties, bruises on some part of the plaintiff's body, bleeding and swollen marks on the plaintiff's face as evidence to support the plaintiff's claim concerning the husband's cruelty. The honorable judge in his judgment states:

"It is unreasonable to impose (a burden) on a wife who claims that she has been beaten by her husband to bring witnesses as it is very unlikely that a husband will call two male witnesses or one male witness combined with two female witnesses whenever he wants to beat his wife. In this type of case, evidence in the form of

\footnotetext{
$47 \quad$ At 73.

48 Qarinah may in certain circumstances attain the degree of yaqin (certainty). See the Mejelle, article 1740. See also Rawalpindi Supreme Court case of Mst. Naseem Akhtar v. Muhammad Rafique. PLD 2005 293.

$49 \quad$ (1997) $11 \mathrm{JH} 47$.
} 
shahädah is not required as bayyinah and qarinah are sufficient."

The dictum of this case was later followed by the famous case of Shahela Majid v. Roslan. ${ }^{50}$

\section{HOW TO PROVE TA'LITQ}

Literally, $\operatorname{ta}$ ' $\mathrm{l} q$, which comes from the root word , means to suspend. Technically, it means to suspend the happening of a divorce upon occurrence of a certain event. This means that under $t a$ ' $l i q$ divorce, talāq comes into effect not on the proclamation of taläq by the husband but at the time when the stipulated condition is fulfilled. Section 2 of the Islamic Family Law (Federal Territories) Act 1984 defines ta ' $\mathrm{l} i q$ as a promise expressed by the husband after solemnization of marriage in accordance with hukum syara' and the provisions of the Act.

Apparently, proving ta ' li $q$ is almost the same as proving fasakh. It will depend on the ground of $t a$ ' liq that is used by the applicant; whether such ground falls under a civil or a criminal allegation. For example, if the wife alleges that she has been deserted for more than four months, this requires the civil standard of proof (zan) whereas if the wife alleges that she has been abused or assaulted by the husband then her claim needs to be proved on a criminal standard i.e. beyond reasonable doubt (zan al-ghälib).

In practice, however, the Shariah Courts in Malaysia seem to ignore this category. They insist on the requirement of proving ta 'liq by producing at least two male witnesses. For example in Rokiah bt Mohamad v. Abdul Aziz, ${ }^{51}$ the wife made a claim of ta' liq $q$ divorce on the ground that the husband had failed to provide maintenance for more than four months. The Shariah Subordinate Court had rejected her claim because of insufficiency of evidence. The court by referring to the book of 'I'änah al-Tālibin stated as follows:

\footnotetext{
$50 \quad$ Jurnal Syariah, 8:2 [2000] 155.

51 (1988) $6 \mathrm{JH}$ 156. It was very unfortunate that the case of Fatimah $v$. Norazmi (2001) 14 JH 65 did not refer to the case of Abdul Hanif v. Rabiah (1997) $11 \mathrm{JH} 47$ that had been decided two years earlier.
} 
"As in the present case, it must be proved by two male witnesses. It is not sufficient to call one male witness together with two female witnesses or one male witness together with the plaintiff's oath as brought by the plaintiff.”

In the case of Norazaha bin Ariffin v. Rohana binti Othman, ${ }^{52}$ the wife made a claim of $t a ' t i q$ divorce on the ground that the husband had left her for more than four months. The Shariah Subordinate Court had granted her claim based on the evidence of one witness and her oath as provided under section 88 . However, on appeal by the husband, the Shariah High Court revised the decision on the ground that the said method did not apply to ta' $\operatorname{liq}$ cases. The court insisted on the requirement of two male witnesses. ${ }^{53}$

It is important to highlight section 88 of SCEA 1997 here as it provides another method of proof. Section 88 states:

"Where in a civil suit, ${ }^{54}$ there is only one witness produced by the plaintiff, the evidence of such witness shall only be admissible if his evidence is given together with the oath of the plaintiff"

Despite this section allowing evidence of a single witness together with claimant's oath, ${ }^{55}$ it does not mention clearly about the application of this section to divorce (talāq) cases. ${ }^{56}$ Arguably, it may also apply to

$52 \quad$ (1999) 13 JH91.
At 93 and 102.

Civil suit refers to mal cases i.e. matters that fall under the Shariah Court civil jurisdiction as provided under section 46 of Administration of Islamic Law (Federal Territories) Act 1993.

This kind of proof is subjected to various opinions among the jurists. Zāhirī school applies this method in almost all cases except hudūd. See Ibn Hazm, al-Muhalla, vol. 10, 274. On the other hand Hanafi school rejected this method in all cases. See Al-Jașșaș, Abī Bakr Aḥmad, Aḥkām al-Qur'ān, (Beirut: Dār al-Iḥya’ al-Turāth, 1985), vol. 3, 247. While Shāfi 'i school limits its application to property matters only. See Al-Nawāwī, Muhyiddīn Abū Zakariya, Minhāj al-Tālibìn, English trans. by Howard, (Lahore: Law Publishing Company), 518.

Case of Norazaha bin Ariffin $v$ Rohana binti Othman had attempted to apply the section but was rejected on appeal. 
talāq cases because Rule 1(a) of the Rules of Oath 2006 clearly provides that oath is applicable in all matrimonial matters including divorce. ${ }^{57}$ Hence, it can be concluded here that the decision of the Shariah Subordinate Court is in line with section 88 of SCEA 1997 and the spirit of the discussion.

With due respect, it is submitted that the decision by the Shariah Appellate Court of Kelantan in the case of Wan Shiram v. Nik Adura ${ }^{58}$ is also incorrect. Here, the court required a higher standard of proof than the normal standard in civil allegation. To quote:

"The important issue in the present case is that the respondent applied for $t a{ }^{\prime} i q$ due to the fact that the appellant had deserted her for more than four months. Thus, the burden of proof is on the respondent ... Proof that is needed is the testimony of two male witnesses who clearly saw the fact and without any element of doubts.”

This case shows that even the Shariah Court of Appeal has restricted the scope of proving by limiting to one kind of proof only (i.e. two male witnesses) in proving $t a^{\prime} l i q$ and consequently had imposed a very high standard of proof. ${ }^{59}$

In the case of Adiba Yasmin $v$ Abdul Rani, ${ }^{60}$ the wife applied for ta 'liq divorce due to her husband's cruelty. Unfortunately, the Shariah Court insisted on the requirement of two male witnesses who saw the husband beating the wife.

$57 \quad$ See Jabatan Kehakiman Shariah Malaysia, Practice Direction 2006 'Rules on Oath' (Kaedah Yamin 2006). Prior to this Rule, it was not clear whether oath can be administered in divorce cases or not. The reason is simply because of differences of opinion among the jurists as discuss earlier. (2002) 15 JH 97 at 100.

$59 \quad$ See also the case of Siti Khadijah v. Mohd. Yatim (2001) 14 JH 109. This case is about the application of divorce under $t a{ }^{\prime} l i q$. The court in this case did not only require two male witnesses to prove the missing of the husband but insisted that the witnesses must directly see with their own eyes about the facts in issue.

$60 \quad$ (1990) $7 \mathrm{JH} 44$. 
Thus, it is suggested that in future cases, the case of Rabiah $v$ Haniff ${ }^{61}$ should be respectfully followed.

\section{CONCLUSION}

Although a husband has the right to divorce his wife, Islam stresses that it should be done equitably. As justice is deemed to be for all, a woman has a right to be informed of her status. If she is divorced, she is entitled to claim and receive certain rights. When one party, normally the husband, fails to appreciate this, it certainly creates problems and could lead to injustice to the other party, especially the wife.

If the husband has treated the wife badly or unjustly, under the Islamic Law, she is entitled to dissolve the marriage. Unfortunately, in some cases it is observed that the wives have been burdened with unnecessary requirements in order to prove their claims. This situation, certainly, has caused them grievous injustice and must be avoided in the future.

Islam has laid down a clear and systematic concept of proving, variety kinds of proof and a very rationale standard of proof. Failure to appreciate all these will cause injustice to the relevant parties. To keep up with the modern development, Muslim jurists as well as the judges must attempt to forge effective solutions. We need to strike a balance between preserving the harmonization of the family institution with the rights of the aggrieved party. To achieve this, the concept of burden and standard of proof must really be well understood and be correctly applied. The principle of 'best evidence rule' must also be adhered to.

The application of oath in divorce cases needs to be reviewed. All the jurists agree that oath can be applied in order to affirm the status quo of the parties in divorce cases but only a few allow it to be used as evidence. The facts are, with the new development, evidence also appears in many forms including qarinah. It is suggested, therefore, to consider strong qarinah as a form of bayyinah and consequently to be applied together with oath in proving taläq, fasakh and ta 'liq cases. Nevertheless, prior to the administration of the oath, it is imperative that the court advises the relevant parties about the serious implications of not abiding by the oath. 